J. Clin. Chem. Clin. Biochem.

Vol. 28, 1990, pp. $937-941$

(C) 1990 Walter de Gruyter \& Co.

Berlin $\cdot$ New York

\title{
Interference of Immunoglobulins in the Radioimmunoassay of Human $\beta$-Endorphin
}

\author{
By Takuma Hashimoto ${ }^{1}$, Susum Miyabo ${ }^{2}$, Machiko Nishibu ${ }^{1}$, Fujitsugu Matsubara ${ }^{1}$ and Shunsuke Migita ${ }^{3}$ \\ 1 Department of Laboratory Medicine, Kanazawa University School of Medicine, Kanazawa, Japan \\ 2 Third Department of Internal Medicine, Fukui Medical College, Fukui, Japan \\ ${ }^{3}$ Department of Molecular Immunology, Cancer Research Institute of Kanazawa University, Kanazawa, Japan
}

(Received February 14/September 9, 1990)

\begin{abstract}
Summary: The interference of immunoglobulins in the radioimmunoassay (RIA) of human $\beta$-endorphin was investigated. Human IgM showed no cross-reactivity. Human IgA showed a weak cross-reaction, but the dilution curve of $\operatorname{IgA}$ did not show parallelism with the standard curve of $\beta$-endorphin, thus indicating its antigenic difference. The dilution curves of human IgG showed $0.18 \%$ displacement with respect to the human $\beta$-endorphin standard curve, with good parallelism. Moreover, five patients with multiple myeloma of the IgG type showed falsely elevated $\beta$-endorphin levels. We investigated the possibility that certain IgGs may be responsible for the displacement of $\left[{ }^{125} \mathrm{I}\right] \beta$-endorphin in the $\beta$-endorphin kit. The apparent $\beta$-endorphin level of plasma from multiple myeloma patients was markedly decreased after affinity chromatography of the serum on protein A-Sepharose.
\end{abstract}

In another 3 patients with multiple myeloma, we examined IgG interference by measuring the $\beta$-endorphin levels in their lyophilized IgG diluted with saline. The results demonstrated high values of $20.2,25.5$ and $21.2 \mathrm{pmol} / 1$ respectively, also showing good parallelism. These immunological parallels to human $\beta$-endorphin verify that a part of the amino acid sequence of human $\operatorname{IgG}$ is similar to that of human $\beta$-endorphin.

Consequently, in the measurement of $\beta$-endorphin with polyclonal antibody, the results may sometimes be spuriously high due to cross-reaction with $\mathrm{IgG}$, e. g. in patients with IgG myeloma. To avoid IgG interference, a specific monoclonal antibody to synthetic $\beta$-endorphin should be used rather than polyclonal antibodies.

\section{Introduction}

Many reports on $\beta$-endorphins have been published during the past decade $(1-9)$. Clinical studies indicate that the intravenous administration of synthetic $\beta$ endorphin exerts beneficial biological effects on patients with cancer pain (10), in narcotic abstinence syndrome (10), in schizophrenic behaviour, and depression (11). An interesting finding has been reported by Julliard et al. (12), who discovered an apparent structural similarity between a high molecular weight immunoreactive $\beta$-endorphin and a fragment of immunoglobulin $\mathrm{G}\left(\mathrm{IgG}_{1}\right)$ in extracts from the human placenta. Surprisingly, considerable structural simi- larities between corticotropin and a fragment of IgG were also revealed. These findings stimulated our interest in the connection between the structures of hormones and immunoglobulins and gave rise to several interesting questions.

1) Does $\beta$-endorphin radioimmunoassay show immunoreactivity, not only with human IgG, but also with IgA and IgM?

2) Does circulating IgG interfere with the human $\beta$ endorphin radioimmunoassay?

3) Does human IgG show immunoreactivity in other human pituitary hormone radioimmunoassays? 
No information concerning these questions has hitherto been reported. We therefore investigated the influence of human IgG on the radioimmunoassay for human pituitary hormones, including $\beta$-endorphin in order to elucidate possible existing homologies in the amino acid sequences of these physiologically unrelated substances.

\section{Normal subjects and patients}

Normal $\beta$-endorphin values were determined in 82 normal healthy volunteers (43 males; 49 females; aged 18-65) whose blood was collected between 0800 and 0900 . The blood samples $(5-10 \mathrm{ml})$ were collected in plastic tubes by venipuncture containing $2 \mathrm{~g} / \mathrm{l}$ EDTA; centrifuged within $15 \mathrm{~min}$, the plasma separated and immediately frozen at $-20^{\circ} \mathrm{C}$. Six of the volunteers were given metyrapone, $2.0 \mathrm{~g}$ orally at $9 \mathrm{a}$. m., with blood samples drawn immediately beforehand and after $6 \mathrm{~h}$ and $8 \mathrm{~h}$. From the volunteer group blood samples for $\beta$-endorphin, corticotropin and cortisol were obtained from 6 subjects at $11 \mathrm{p} . \mathrm{m}$., followed by the administration of $1.0 \mathrm{mg}$ of dexamethasone orally. At $6 \mathrm{a} . \mathrm{m}$. and $8 \mathrm{a} . \mathrm{m}$. further blood samples were obtained. Six more normal subjects underwent an insulin tolerance test (monocomponent insulin $0.1 \mathrm{U} / \mathrm{kg}$ ). During this test blood samples were taken via an intravenous cannula at $-30,-15,0,15,30,60,90$, and $120 \mathrm{~min}$ and assayed for glucose, corticotropin, $\beta$-endorphin, cortisol and insulin.

Five patients with pituitary corticotropin-dependent Cushing's disease who had been bilaterally adrenalectomized and five patients with Addison's disease receiving corticosteroid replacement therapy were studied. Replacement therapy was omitted on the morning of the study; venous blood samples were taken at $0900 \mathrm{~h}$ and thereafter at $30 \mathrm{~min}$ intervals for $3 \mathrm{~h}$, and were assayed for corticotropin, $\beta$-endorphin and cortisol. Five patients with multiple myeloma of the IgG type (3 Lambda, 2 Kappa) had plasma taken for $\beta$-endorphin assay. These samples were assayed with and without affinity chromatography on staphylococcal protein A-Sepharose.

\section{Materials and Methods}

Concentrations of immunoreactive $\beta$-endorphin were determined by means of a commercial radioimmunoassay kit developed by the New England Nuclear Company, Boston, MA, USA, with antiserum from rabbits prepared against synthetic human $\beta$-endorphin (synthesized by the Peptide Division of the Beckman Company, FRG). Synthetic $\beta$-endorphin was labelled with $\mathrm{Na}^{125} \mathrm{I}$ using chloramine $\mathrm{T}$. The specific activity of $\left[{ }^{125} \mathrm{I}\right] \beta$ endorphin ranged from 56.1 to $83.6 \mathrm{TBq} / \mathrm{mmol}$. The assay was performed according to the following protocol. Briefly, $0.1 \mathrm{ml}$ specimen was used. Synthetic human $\beta$-endorphin served as a standard. The antiserum to $\beta$-endorphin was used at a final dilution of $1: 8000$. Separation of the bound, from free antigen, was achieved by adsorption onto activated charcoal. The specificity of the $\beta$-endorphin antiserum was $50 \%$ for $\beta$-lipotropic hormone ( $\beta$-lipotropin), less than $0.01 \%$ for $\alpha$-endorphin and $\alpha$-melanocyte stimulating hormone ( $\alpha$-melanotropin), and less than $0.004 \%$ for leu-enkephalin and met-enkephalin. The minimal detectable dose was $5.0 \mathrm{pmol} / \mathrm{l}$. The intra- and interassay variation were $5.6 \%$ and $12 \%$ respectively. To ensure the accuracy of our RIA in the determination of human plasma $\beta$ endorphin levels, we performed dexamethasone supression tests, insulin hypoglycaemia tests and metyrapone tests on normal healthy subjects; the results were in agreement with previously reported values for $\beta$-endorphin in these tests. In our laboratory the $\beta$-endorphin levels ranged from $5-30$ $\mathrm{pmol} / \mathrm{l}$.

Highly purified human IgG was obtained from Cappel Labs West Chester, PA, USA, (lot no. 29153), Kabi Co. (lot no. 58803), Sweden, and Miles Labs, Indiana, USA (lot no. 8376); human IgA from Miles Labs (lot no. 21277) and human IgM from Miles Labs (lot no. 9675). Human immunoglobulins (IgG, IgA and IgM) were measured by laser nephelometry (Hoechst Co. FRG). The M-protein types and light chain types were identified by Beckman Paragon Immunofixation Electrophoresis (Beckman, Brea, CA, USA). For affinity chromatography of the samples on Protein A-Sepharose, we used the Immunopure IgG Purification Kit (Pierce Chemical Co., USA) according to the manufacturer's instructions.

\section{Results}

\section{Plasma $\beta$-endorphin concentrations}

Table 1 shows the circulating plasma $\beta$-endorphin levels in 82 healthy normal subjects, 5 bilaterally adrenalectomized patients with Cushing's disease and 5 patients with Addison's disease. During the dexamethasone suppression tests the plasma $\beta$-endorphin levels fell in each subject and rose during the insulininduced hypoglycaemia and metyrapone tests. All the patients with Cushing's disease and Addison's disease had elevated plasma $\beta$-endorphin and corticotropin concentrations.

Tab. 1. Concentrations (mean $\pm \mathrm{SD}$ ) of plasma $\beta$-endorphin (pmol/l) in normal subjects, patients with bilaterally adrenalectomized Cushing's disease and Addison's disease.

* $\mathrm{P}<0.01,{ }^{* *} \mathrm{P}<0.001$

\begin{tabular}{lrrcrc}
\hline Subjects & $\mathrm{n}$ & Basal level & Post metyrapone & Post dexamethasone & $\begin{array}{c}\text { Post insulin } \\
\text { hypoglycaemia }\end{array}$ \\
\hline Normal males & 43 & $7.9 \pm 0.9$ & & \\
Normal females & 49 & $7.7 \pm 1.1$ & $26.1 \pm 2.1^{*}$ (a) & $<5.0 \sim 6.1^{*}$ (a) & $18.2 \pm 3.2^{*}$ (a) \\
Normal males & 6 & $7.7 \pm 0.8$ & & \\
Normal males & 6 & $7.8 \pm 1.0$ & & \\
Cushing's disease & 5 & $68.2 \pm 5.6^{* *}(\mathrm{~b})$ & & \\
Addison's disease & 5 & $91.5 \pm 11.2^{* *}(\mathrm{~b})$ & & \\
\hline
\end{tabular}

Statistical analysis: (a) Paired t test (basal level vs post drug administration)

(b) Student t test

J. Clin. Chem. Clin. Biochem. / Vol. 28, 1990 / No. 12 
Tab. 2. Plasma $\beta$-endorphin levels and related data in 5 patients with multiple myeloma

\begin{tabular}{|c|c|c|c|c|c|c|c|c|c|c|c|c|c|c|}
\hline \multirow{2}{*}{$\begin{array}{l}\mathrm{Pa}- \\
\text { tient } \\
\text { No. }\end{array}$} & \multirow[t]{2}{*}{ Sex } & \multirow[t]{2}{*}{$\begin{array}{l}\text { Age } \\
\text { (a) }\end{array}$} & \multicolumn{6}{|c|}{ Protein concentrations $(\mathrm{g} / \mathrm{l})$} & \multicolumn{3}{|c|}{$\begin{array}{l}\text { Immunoglobulin concen- } \\
\text { trations }(\mathrm{mg} / \mathrm{l})\end{array}$} & \multirow{2}{*}{$\begin{array}{l}\text { Light } \\
\text { chain } \\
\text { type }\end{array}$} & \multicolumn{2}{|c|}{$\begin{array}{l}\beta \text {-Endorphin con- } \\
\text { centrations (pmol/l) } \\
\text { without with }\end{array}$} \\
\hline & & & $\begin{array}{l}\text { To- } \\
\text { tal } \\
\text { pro- } \\
\text { tein }\end{array}$ & $\begin{array}{l}\text { Al- } \\
\text { bu- } \\
\text { min }\end{array}$ & $\begin{array}{l}\alpha 1- \\
\text { globuli }\end{array}$ & $\begin{array}{l}\alpha 2- \\
\text { ins }\end{array}$ & $\beta-$ & $\gamma-$ & $\mathrm{IgG}$ & $\operatorname{IgM}$ & $\operatorname{IgA}$ & & \multicolumn{2}{|c|}{$\begin{array}{l}\text { purification by pro- } \\
\text { tein A-Sepharose }\end{array}$} \\
\hline 1 & 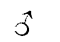 & 37 & 113 & 36.6 & 1.6 & 4.6 & 4.6 & 65.5 & 69100 & 460 & 680 & Kappa & 23.4 & 9.1 \\
\hline 2 & 9 & 40 & 86 & 39.8 & 2.6 & 5.2 & 3.9 & 34.6 & 36300 & 620 & 1500 & Lambda & 16.3 & 8.8 \\
\hline 3 & q & 44 & 101 & 33.8 & 6.6 & 11.6 & 8.1 & 40.9 & 49250 & 390 & 980 & Lambda & 18.1 & 8.2 \\
\hline 4 & $\hat{\jmath}$ & 67 & 112 & 35.8 & 6.7 & 14.6 & 4.5 & 50.4 & 53200 & 420 & 720 & Lambda & 15.2 & 5.2 \\
\hline 5 & $\hat{j}$ & 70 & 102 & 34.1 & 1.8 & 4.4 & 4.5 & 57.2 & 61150 & 510 & 950 & Kappa & 19.4 & 5.1 \\
\hline \multicolumn{3}{|c|}{ Reference ranges } & $\begin{array}{l}66- \\
81\end{array}$ & $\begin{array}{l}39- \\
49\end{array}$ & $\begin{array}{l}1.0- \\
3.5\end{array}$ & $\begin{array}{l}5.5- \\
11.8\end{array}$ & $\begin{array}{l}4.3- \\
9.0\end{array}$ & $\begin{array}{l}5.5- \\
14.1\end{array}$ & $\begin{array}{l}13000- \\
17740\end{array}$ & $\begin{array}{l}600- \\
1480\end{array}$ & $\begin{array}{l}1780- \\
3550\end{array}$ & & $\begin{array}{c}* 18.5 \pm \\
1.4\end{array}$ & $\begin{array}{l}7.3 \pm \\
0.9\end{array}$ \\
\hline
\end{tabular}

Table 2 shows the $\beta$-endorphin levels in patients with multiple myeloma of the IgG type. All the patients showed high plasma $\beta$-endorphin levels but within the normal range, but then showed a marked decline after affinity chromatography on staphylococcal protein ASepharose, which suggests IgG interference.

The effect of human IgG, A, M, on the $\beta$ endorphin radioimmunoassay

The dilution curve of human $\operatorname{IgA}$ and $\operatorname{IgM}$ did not show parallelism with the human $\beta$-endorphin standard curve, suggesting the IgA and IgM do not possess sequence homologies to $\beta$-endorphin. In contrast, commercial human IgG causes a significant displacement of labelled $\beta$-endorphin, with good parallelism (fig. 1); i. e. the dilution curves of IgG from Miles Labs, Cappel Labs and Kabi company showed $0.20 \%$, $0.18 \%$ and $0.16 \%$ cross-reactivity, respectively, with the standard curve for $\beta$-endorphin, thus indicating



Fig. 1. Inhibition curves associated with various human immunoglobulins in the human $\beta$-endorphin radioimmunoassay. immunological identity. After affinity chromatography of the serum on staphylococcal protein A-Sepharose (13), no immunological cross-reactivity was observed.

The effect of IgG on human pituitary hormone radioimmunoassays

No immunological effect of $\operatorname{IgG}$ was found in the radioimmunoassays for lutropin, follitropin, thyrotropin, prolactin or somatotropin, indicating that there is no immunological similarity between the amino acid sequences of these hormones and that of $\operatorname{IgG}$.

\section{Discussion}

The circulating human $\beta$-endorphin levels were checked by radioimmunoassay and were found to be $5-30 \mathrm{pmol} / 1$. Moreover, the $\beta$-endorphin response in the dexamethasone suppression test, insulin hypoglycaemia test and metyrapone test showed results corresponding to those previously reported $(14-17)$.

In 1980, Julliard et al. (12) discovered structual homologies between $\beta$-endorphin and IgG using a computer program. They synthesized a fragment of human IgG heavy chain 363 to 379 (VSLTCLVKGFYPSDIAV) by solid-phase techniques and reported that this fragment showed 0.18 percent displacement of the human $\beta$-endorphin tracer, with good parallelism. Our present study concurs with Julliard's finding (12).

This result suggested that spuriously high $\beta$-endorphin levels may be obtained in patients with high $\gamma$-globulinaemia. Therefore a preliminary examination of three patients with IgG myeloma was carried out. Their lyophilized IgG, diluted with saline to a concentration of $177,185,162 \mathrm{~g} / \mathrm{l}$, indeed showed high 
$\beta$-endorphin values, i.e. $20.2,25.5,21.2 \mathrm{pmol} / \mathrm{l}$, respectively, but showed negligible $\beta$-endorphin levels after the removal of IgG proteins by affinity chromatography on protein A-Sepharose. It is therefore concluded that the pseudo- $\beta$-endorphin activity of human plasma proteins is essentially due to the effect of IgG per se. To cross check the accuracy of these results we pre-added $\beta$-endorphin to the IgG solution from the same patients and carried out affinity chromatography. The subsequent recovery of $\beta$ endorphin was $95.6 \pm 2.3 \%$ (Mean $\pm \mathrm{SE}$ ), thus demonstrating that there were no changes in concentration of $\beta$-endorphin in the IgG solution. This study clearly excludes the possibility that the $\beta$-endorphin is noncovalently linked to IgG. Moreover, in order to confirm our hypothesis we performed further experiments using the plasma from five other patients suffering from IgG myeloma. We studied the $\beta$-endorphin levels before and after staphylococcal affinity chromatography on protein A-Sepharose. As shown in table 2 the plasma $\beta$-endorphin levels were elevated before and markedly decreased after. These results clearly indicate $\operatorname{IgG}$ interference in the human $\beta$-endorphin radioimmunoassay.

Julliard et al. (12) reported that their studies had led to the unexpected recognition of several homologies in the amino acid sequences of two physiologically unrelated substances, such as pituitary hormone ( $\beta$ endorphin and corticotropin) and the constant chain of an IgG. We therefore conducted a further study on the effect of IgG proteins on the radioimmunoassays of several pituitary hormones, in order to investigate the possibility of other unexpected relationships. In our studies of peptide hormones, no immu- nological similarities to IgG were found. However, the observation made by Julliard et al. (12) does seem important, and there may be other cases of substances arising from the same origin, which previously have been thought to be unrelated. Very recently a study by Campino et al. (18) described that immunoreactive human growth hormone, in a patient with acromegaly, is in fact IgG. Additional studies are expected.

Through our studies, it has become clear that to avoid IgG interference a specific monoclonal antibody which recognises the epitope of $\beta$-endorphin is preferable to using polyclonal antibodies raised in animals. The use of such a specific monoclonal antibody would avoid the spuriously high results for $\beta$-endorphin in patients with high IgG levels. Recently Voellmy et al. (19) reported a two-site immunoradiometric assay for human $\beta$-endorphin using a polyclonal rabbit anti- $\beta$-endorphin antibody and an ${ }^{125} \mathrm{I}-$ labeled monoclonal mouse antibody 3-E7, which binds to the $\mathrm{N}$-terminal region of $\beta$-endorphin. If no IgG effect is demonstrated with this newly developed monoclonal antibody method, we can anticipate greater accuracy and reliability in the determination of $\beta$-endorphin concentrations.

\section{Acknowledgement}

We are indebted to Dr. Ellen Ingham for encouragement, helpful discussions, and comments. We also thank Mrs Tsuyuji Yoshimoto and Mrs Emi Yokoyama for their excellent secretarial assistance, and Miss Hermione Elliott for her help with the English in the preparation of this manuscript.

This work was supported in part by the Japan Clinical Pathology Foundation for International Exchange and the Clinical Pathology Foundation of Japan.

\section{References}

1. Krieger, D. T., Liotta, A. S., Brownstein, M. J. \& Zimmerman, E. A. (1980) ACTH, $\beta$-lipotropin, and related peptides in brain, pituitary, and blood. In: The Recent Progress in Hormone Research, Vol. 33 (Greep, R. O., ed.) pp. 277-344, Academic Press, Ing., New York.

2. Watson, S. J., Lopez, J. F., Young, E. A., Vale, W., Rivier, J. \& Akil, H. (1988) Effects of low dose ovine corticotropinreleasing hormone in humans: Endocrine relationships and $\beta$-endorphin $/ \beta$-lipotropin responses. J. Clin. Endocrinol. Metab. 66, 10-15.

3. Rupprecht, R., Lesch, K. P., Muller, U., Beck, G., Beckmann, H. \& Schulte, H. M. (1989) Blunted adrenocorticotropin but normal $\beta$-endorphin release after human corticotropin-releasing hormone administration in depression. J. Clin. Endocrinol. Metab. 69, 600-603.

4. Troullos, E. S., Hargreaves, K. M., Goldstein, D. S., Stull, R. \& Dionne, R. A. (1989) Epinephrine suppresses stressinduced increases in plasma immunoreactive $\beta$-endorphin in humans. J. Clin. Endocrinol. Metab. 69, 546-551.
5. Giugliano, D., Cozzolino, D., Salvatore, T., Torella, R., Franchimont, P., D'onofrio, F. \& Lefebvre, P. J. (1988) Altered metabolic and hormonal responses to epinephrine and $\beta$-endorphin in human obesity. J. Clin. Endocrinol. Metab. 67, 238-244.

6. Buydens, P., Velkeniers, B., Golstein, J., Finne, E. \& Vanhaelst, L. (1988) The effect of $\beta$-endorphin on basal and TRH-stimulated TSH release in conscious male rats. Horm. Metabol. Res. 20, 687-690.

7. Genazzani, A. R., Petraglia, F., Facchinetti, F., Golinelli, S., Oltramari, P., Santoro, V. \& Volpe, A. (1988) Evidences for a dopamine-regulated peripheral source of circulating $\beta$-endorphin. J. Clin. Endocrinol. Metab. 66, 279-282.

8. Iranmanesh, A., Lizarralde, G., Johnson, M. L. \& Veldhuis, J. D. (1989) Circadian, ultradian, and episodic release of $\beta$-endorphin in men, and its temporal coupling with cortisol. J. Clin. Endocrinol. Metab. 68, 1019-1026. 
9. Herman, B. H., Arthur-Smith, A., Hammock, M. K. \& Josephs, S. (1988) Ontogeny of $\beta$-endorphin and cortisol in the plasma of children and adolescents. J. Clin. Endocrinol. Metab. 67, 186-190.

10. Catlin, D. H., Hui, K. K., Loh, H. H. \& Li, C. H. (1977) $\beta$-endorphin: initial clinical studies. In: The Endorphins in Mental Health Research (Usin, E., Bunniy, W. E. \& Kline, N. S., eds.) pp. 535-544, Macmillan Press Ltd., London.

11. Gunne, L. M., Lindstrom, L. \& Widerlov, E. (1977) Possible role of endorphins in schizophrenia and other psychiatric disorders. In: The Endorphins in Mental Health Research (Usdin, E., Bunniy, W. E. \& Kline, N. S., eds.) pp. 547-552, Macmillan Press Ltd., London.

12. Julliard, J. H., Shibasaki, T., Ling, N. \& Guillemin, R. (1980) High-molecular-weight immunoreactive $\beta$-endorphin in extracts of human placenta is a fragment of immunoglobulin G. Science 208, 183-185.

13. Goding, J. W. (1978) Use of staphylococcal protein A as an immunological reagent. J. Immunol. Methods 20, $241-$ 253.
14. Nakao, K., Nakai, Y., Oki, S., Horii, K. \& Imura, H. (1978) Presence of immunoreactive $\beta$-endorphin in normal human plasma. J. Clin. Invest. 62, 1395-1398.

15. Wardlaw, S. L. \& Frantz, A. G. (1979) Measurement of $\beta$ endorphin in human plasma. J. Clin. Endocrinol. Metab. $48,176-178$.

16. Wiedemann, E., Saito, T., Linfoot, J. A. \& Li, C. H. (1979) Specific radioimmunoassay of human $\beta$-endorphin in unextracted plasma. J. Clin. Endocrinol. Metab. 49, 478-481.

17. Yoshimi, H., Matsukura, S., Sueoka, S., Yokota, M. \& Hirata, Y. (1978) Biosynthesis and multiplicity of immunologic activities of $\beta$-endorphin. Horumon To Rinsho 26, $781-785$.

18. Campino, C., Szecowka, J., Michelsen, H. \& Seron-Ferre, M. (1990) Certain large forms on circulating immunoreactive human growth hormone are in fact immunoglobulins. J. Clin. Endocrinol. Metab. 70, 601-605.

19. Voellmy, D. R., Kulling, P., Gramsch, C., Hani, M., Mehraein, P., Messiha, F. S. \& Pasi, A. (1988) A novel two-site immunoradiometric assay for $\beta$-endorphin using nitrocellulose as solid phase. Neurosci. Biobeh. Rev. 12, 199-204.

Dr. T. Hashimoto

Department of Laboratory Medicine Kanazawa University School of Medicine 13-1, Takara-machi, Kanazawa Ishikawa, 920, Japan 
